\title{
Genetics and mapping of a new anthracnose resistance locus in Andean common bean Paloma
}

\author{
Sandra Aparecida de Lima Castro ${ }^{1}$, Maria Celeste Gonçalves-Vidigal ${ }^{1 *}$, Thiago Alexandre Santana Gilio', \\ Giselly Figueiredo Lacanallo', Giseli Valentini', Vanusa da Silva Ramos Martins' ${ }^{1}$ Qijian Song ${ }^{2}$, \\ Marta Zulema Galván ${ }^{3}$, Oscar P. Hurtado-Gonzales ${ }^{2}$ and Marcial Antonio Pastor-Corrales ${ }^{2^{*}}$
}

\begin{abstract}
Background: The Andean cultivar Paloma is resistant to Mesoamerican and Andean races of Colletotrichum lindemuthianum, the fungal pathogen that causes the destructive anthracnose disease in common bean. Remarkably, Paloma is resistant to Mesoamerican races 2047 and 3481, which are among the most virulent races of the anthracnose pathogen. Most genes conferring anthracnose resistance in common bean are overcome by these races. The genetic mapping and the relationship between the resistant Co-Pa gene of Paloma and previously characterized anthracnose resistance genes can be a great contribution for breeding programs.

Results: The inheritance of resistance studies for Paloma was performed in $F_{2}$ population from the cross Paloma (resistant) $\times$ Cornell 49-242 (susceptible) inoculated with race 2047, and in $F_{2}$ and $F_{2: 3}$ generations from the cross Paloma (resistant) $\times$ PI 207262 (susceptible) inoculated with race 3481. The results of these studies demonstrated that a single dominant gene confers the resistance in Paloma. Allelism tests performed with multiple races of C. lindemuthianum showed that the resistance gene in Paloma, provisionally named $\mathrm{Co}-\mathrm{Pa}$, is independent from the anthracnose resistance genes Co-1, Co-2, Co-3, Co-4, Co-5, Co-6, Co-12, Co-13, Co-14, Co-15 and Co-16. Bulk segregant analysis using the SNP chip BARCBean6K_3 positioned the approximate location of Co-Pa in the lower arm of chromosome Pv01. Further mapping analysis located the Co-Pa gene at a $390 \mathrm{~kb}$ region of Pv01 flanked by SNP markers SS82 and SS83 at a distance of 1.3 and $2.1 \mathrm{cM}$, respectively.

Conclusions: The results presented here showed that Paloma cultivar has a new dominant gene conferring resistance to anthracnose, which is independent from those genes previously described. The linkage between the Co-Pa gene and the SS82 and SS83 SNP markers will be extremely important for marker-assisted introgression of the gene into elite cultivars in order to enhance resistance.
\end{abstract}

Keywords: Phaseolus vulgaris, Colletotrichum lindemuthianum, Genetic resistance, KASP markers, SNP markers

\section{Background}

The common bean (Phaseolus vulgaris L.) is a rich and inexpensive source of protein, fiber, and other important micronutrients, and a vital component for fighting hunger among millions of the poorest populations from Africa and Latin America [1, 2]. Multiple phenotypic,

\footnotetext{
* Correspondence: mcgvidigal@uem.br; talo.pastor-corrales@ars.usda.gov 'Departamento de Agronomia, Universidade Estadual de Maringá, Maringá, Paraná, Brazil

${ }^{2}$ Soybean Genomics and Improvement Laboratory, United States Department of Agriculture, Agricultural Research Service, Beltsville, MD, USA

Full list of author information is available at the end of the article
}

molecular and genomic traits distinguish the diversity of wild and domesticated common beans into two genetically differentiated gene pools known as Mesoamerican and Andean [3-5]. Mesoamerican and Andean dry beans which are commercially important throughout the world, are cultivated in the North, Central and South America, some countries of Africa and Europe [6].

Among the many diseases of common bean, anthracnose, caused by Colletotrichum lindemuthianum (Sacc. and Magnus) Briosi and Cavara, is one of the most widespread and severe $[7,8]$. Yield reduction in 
susceptible cultivars can reach up to $100 \%$, under conditions of high humidity and moderate temperatures that propitiate the pathogen's growing. Although genetic resistance is the most cost-effective strategy to manage the anthracnose disease, the wide virulence diversity of $C$. lindemuthianum still remains the greatest challenge to develop common bean cultivars with effective and durable anthracnose resistance. Approximately 247 different virulent strains of C. lindemuthianum, known as races, have been described from different worldwide common bean production areas [9].

The virulence diversity of $C$. lindemuthianum falls into two distinct groups that correspond to the Andean and Mesoamerican gene pools of the common bean [10]. Mesoamerican races are virulent on both Mesoamerican and Andean common bean cultivars, however Andean races are more specific: they tend to be more virulent on common beans from the Andean pool [10-12]. Nonetheless, Andean common bean cultivars often provide effective resistance to highly virulent Mesoamerican races of anthracnose pathogen [10]. Genetic diversity exhibited by Mesoamerican common bean cultivars are greater than the one demonstrated by the Andean cultivars [13]. Thus, this is one of the reasons why Mesoamerican common bean has been used more than Andean to investigate resistance sources to anthracnose pathogen.

Previous studies have identified 19 dominant anthracnose resistance genes, which were either identified on Mesoamerican or Andean common bean gene pool. The Mesoamerican genes include: $\mathrm{Co}-2, \mathrm{Co}-3$ (and its alleles $\mathrm{Co}-3^{2}, \mathrm{Co}-3^{3}, \mathrm{Co}-3^{4}, \mathrm{Co}-3^{5}$ ), Co-4 (and it alleles $\mathrm{Co}-4^{2}$, Co- $4^{3}$ ), Co-5 (and its allele Co- $5^{2}$ ), Co-6, Co-11, Co- 16 , Co-17, Co-u, and Co-v [8, 14-26]. The Andean genes include: $\mathrm{Co}-1$ (and its alleles $\mathrm{Co}-1^{2}, \mathrm{Co}-1^{3}, \mathrm{Co}-1^{4}, \mathrm{Co}-1^{5}$ ), Co-12, Co-13, Co-14, Co-15, Co-x, Co-w, Co-y, and Co-z [26-33].

The anthracnose resistance genes have been mapped on seven of the 11 chromosomes of common bean [8, $22-24,30,34]$. Several of these genes have been reported on linkage groups Pv01, Pv04 and Pv11 that contain gene clusters conferring resistance to anthracnose and other diseases [8]. For example, linkage group Pv01 contains a resistance cluster to anthracnose (Co-1, Co-14, Co- $x$ and $C o-w)$, rust (Ur-9), and angular leaf spot (Phg-1) [8, 21].

The search for new sources of Andean resistance to C. lindemuthianum is extremely important for common bean breeding programs in tropical and subtropical regions. Paloma is a white-seeded highly productive Andean bean with desirable agronomic characteristics [35]. Therefore, this cultivar has been recommended by the Instituto Nacional de Tecnologia Agropecuaria
(INTA), Salta, Argentina for cultivation and became popular for human consumption in Europe, especially in Spain and Italy [35]. Experiments conducted in Brazil revealed that Paloma is resistant to Andean and Mesoamerican races of $C$. lindemuthianum.

Given the importance to identify new sources of anthracnose resistance in Andean common bean, the objectives of this study were: 1) to characterize the genetic resistance of Andean common bean cultivar Paloma to C. lindemuthianum, 2) to map the anthracnose resistance gene of cultivar Paloma and 3) to identify molecular markers linked to this resistance gene.

\section{Methods}

Plant materials and phenotypic reaction to Colletotrichum lindemuthianum

The cultivar Paloma and other Andean common bean cultivars were inoculated with Andean races 2, 7, 19, 23, and 55 and with Mesoamerican races 65, 73, 89, 449, 453, 1545, 2047 and 3481 of C. lindemuthianum. The other Andean bean cultivars, with their respective anthracnose resistance genes, included in this study were: Michigan Dark Red Kidney (MDRK) (Co-1), Kaboon $\left(\mathrm{Co}^{2} \mathrm{1}^{2}\right)$, Perry Marrow (PM) $\left(\mathrm{Co}^{3} \mathrm{I}^{3}\right)$, AND $277\left(\mathrm{Co}^{4} \mathrm{1}^{4}\right)$, Widusa $\left(\mathrm{Co}^{-1} \mathrm{1}^{5}\right)$, Jalo Vermelho (JV) (Co12), Jalo Listras Pretas (JLP) (Co-13), Pitanga (Co-14), Corinthiano (Co-15), and Jalo EEP 558 (Co-w, Co- $x$, Co-y and $C o-z)$. Inoculation of $C$. lindemuthianum races was conducted on 10 plants of each cultivar, when the first trifoliate leaf was fully developed (stage $V_{3}$ ). Inoculum for each race was obtained from young bean-pod medium and placed in test tubes containing $5 \mathrm{~mL}$ of water-agar, which were kept upright at $22^{\circ} \mathrm{C}$ for 14 days according to Cárdenas et al. [36]. After 14 days, a spore suspension was prepared with sterile distilled water containing Tween 20 and adjusted to a concentration of $1.2 \times 10^{6}$ spores $\mathrm{mL}^{-1}$. Seedlings with fully developed first trifoliate leaves of common bean cultivars parents, $F_{2}$, and $F_{2: 3}$ were inoculated with spores of selected races of $C$. lindemuthianum as described by Cárdenas et al. [36], using an electric air compressor De Vilbiss number 15. After inoculation, the plants were maintained at $>95 \%$ relative humidity at $20 \pm 2{ }^{\circ} \mathrm{C}$ with controlled luminosity (12 h light of $680 \mathrm{~lx} / 12 \mathrm{~h}$ dark) in a mist chamber for 3 days. After this period, the plants were removed from the mist chamber and transferred to benches with suitable environment at $22{ }^{\circ} \mathrm{C}$ with artificial light $\left(12 \mathrm{~h}\right.$ day length at $\left.25^{\circ} \mathrm{C}\right)$ for 7 days. Anthracnose disease reactions were rated visually using a scale from 1 to 9 , as previously described [37]. Plants with scores from 1 to 3 were considered resistant while those with scores from 4 to 9 were considered susceptible. 


\section{Inheritance test}

In order to determine the resistance inheritance in cultivar Paloma, plants from the $\mathrm{F}_{2}$ populations and parental cultivars were grown under greenhouse conditions. Inoculations with $C$. lindemuthianum races were conducted when the first trifoliate leaf was fully developed (stage $V_{3}$ ). Races 2047 and 3481 were chosen for the inoculations due to the contrasting pathogenic spectrum observed in the parents from the crosses Paloma (resistant) $\times$ PI 207262 (susceptible) and Paloma (resistant) $\times$ Cornell 49-242 (susceptible). Moreover, the races 2047 and 3481 showed high virulence index overcoming the resistance, respectively, in eleven and seven differential cultivars.

Ninety-nine $F_{2}$ plants derived from the cross Paloma (resistant) $\times$ Cornell 49-242 (susceptible) and 10 plants from each parent were inoculated with race 2047. Additionally, another set of $90 \mathrm{~F}_{2}$ plants derived from the cross Paloma (resistant) $\times$ PI 207262 (susceptible) were tested with race 3481 . Similarly, $73 \mathrm{~F}_{2: 3}$ families derived from the cross Paloma (resistant) $\times$ PI 207262 (susceptible) were inoculated with race 3481 . The anthracnose phenotype obtained from these $F_{2: 3}$ families was used to compare the phenotype of their corresponding $\mathrm{F}_{2}$ plants. These populations were produced at the Núcleo de Pesquisa Aplicada à Agricultura (Nupagri) of the Universidade Estadual de Maringá (UEM), Maringá, Paraná, Brazil.

The anthracnose virulence phenotype of races 2047 and 3481 were confirmed by inoculating the set of 12 common bean anthracnose differential cultivars with each of these races [38], because they are used to identify C. lindemuthianum races. Race 2047 was virulent on all differential cultivars, except on G 2333. Further, race 3481 was virulent on seven of the 12 differentials, including G 2333 the most resistant genotype among the 12 differential cultivars [39].

\footnotetext{
Allelism tests

Allelism tests were carried out with 16 different $F_{2}$ populations with the aim to investigate the independence of the anthracnose resistance gene in Paloma from those previously characterized resistance genes in common bean. For that, Paloma was crossed with the following cultivars: Michigan Dark Red Kidney (MDRK) (Co-1), Cornell 49-242 (Co-2), Ouro Negro $\left(\mathrm{Co}^{4} 3^{4}\right)$, TO (Co-4), G $2333\left(\mathrm{Co}_{-} 4^{2}\right)$, PI $207262\left(\mathrm{Co}-4^{3}\right)$, TU $(\mathrm{Co}-5)$, AB 136 (Co-6), Jalo Vermelho (Co-12), Jalo Listras Pretas (Co13), Pitanga (Co-14), Corinthiano (Co-15), Crioulo 159 (Co-16), Amendoim Cavalo, Perla, and Jalo Pintado 2. Paloma was used as the female parent. $F_{1}$ seeds from the crosses mentioned above were grown in pots and the dominant morphological markers, such as pink or purple flower color and indeterminate growth habit in male
}

parents, were verified to confirm hybridization. Variable numbers of $F_{2}$ seeds from each cross, depending on seed availability, were inoculated with the races 65,73 and 2047. Spore increase, inoculum preparation, inoculations and evaluations of the anthracnose phenotypes were performed in the same manner as described in the first section of Methods. To test the hypothesis of independence of the resistance gene in Paloma, the races 65, 73 and 2047 were carefully chosen based on $\mathrm{R} \times \mathrm{R}$ reaction produced in the parents. It is important to mention that races 73 and 65 are the most frequent races in common bean producing areas in Brazil, being present in 13 and 12 out of the 14 states monitored, respectively [9].

\section{Bulk segregant analysis and SNP assay}

Plant tissue from Paloma, PI 207262 and from $73 \mathrm{~F}_{2}$ plants, derived from the cross Paloma $\times$ PI 207262, were collected for total DNA extraction with the PureLink Genomic Plant DNA Purification Kit, following the manufacturer's instructions. DNA bulks were used to perform a bulk segregant analysis to identify SNP markers potentially linked to the resistance gene in Paloma [40]. Briefly, two contrasting DNA bulks were constructed by pooling equal volumes of fluorometrically standardized DNA from six $F_{2}$ plants, which were homozygous for the resistant genotype (resistant bulk, $\mathrm{RB}$ ) and homozygous for the susceptible genotype (susceptible bulk, SB). Homozygous resistant and susceptible $F_{2}$ plants were identified based on the phenotypic assessment evaluation conducted on the $\mathrm{F}_{2: 3}$ families of the same cross inoculated with $C$. lindemuthianum race 3481 .

The bulk segregant analysis with SNP markers was performed at the Soybean Genomics and Improvement Laboratory of the USDA-ARS at the Beltsville Agricultural Research Center, Maryland, USA, using the Illumina BARCBean6K_3 BeadChip, containing 5,399 Single Nucleotide Polymorphism (SNP) DNA markers [41]. SNP genotyping with Illumina BeadChip was carried out as described by Song et al. [42] and performed according to the Infinium HD Assay Ultra Protocol (Illumina, Inc. San Diego, CA). The BeadChip was imaged using the Illumina BeadArray Reader to measure fluorescence intensity. For each SNP locus, alleles were automatically called with the GenomeStudio Genotyping Module v1.8.4 (Illumina, San Diego, CA) and later manually checked. A SNP was considered positive when polymorphism between Paloma (resistant) and PI 207262 (susceptible) was observed and the SB clustered with PI 207262, and the RB clustered with cultivar Paloma.

Positively associated SNP markers derived from BARCBean6K_3 BeadChip were selected to develop Kompetitive Allele Specific PCR (KASP) markers. KASP primer sequences were designed using the software 
PrimerExpress. KASP assays were performed according to the manufacturer's instructions. Briefly, PCR reaction was conducted in a $10 \mu \mathrm{L}$ final volume containing $5 \mu \mathrm{L}$ of 2X premade KASP master mix (LGC, Middlesex, $\mathrm{UK}), 0.14 \mu \mathrm{L}$ of primer mix (Sigma-Aldrich, St. Louis, USA) and 20-40 ng of genomic DNA. After PCR amplification, PCR plates were scanned in a Mx3000P qPCR Reader and allele scores were obtained using the MxPro qPCR software (Agilent, St. Clara, CA).

\section{Statistical analyses}

Segregation analyses of the disease reaction of $99 F_{2}$ individuals from the cross Paloma (resistant) $\times$ Cornell 49-242 (susceptible) and $90 \mathrm{~F}_{2}$ plants from the cross Paloma (resistant) $\times$ PI 207262 (susceptible), inoculated respectively with races 2047 and 3481, were performed with the chi-square $\left(\chi^{2}\right)$ test using the Genes software [43]. These analyses followed the Mendelian segregation hypothesis of $3 \mathrm{R}$ (resistant) to $1 \mathrm{rr}$ (susceptible). The segregation analyses of the $\mathrm{F}_{2: 3}$ families were performed using the chi-square goodness-of-fit test $\left(\chi^{2}\right)$ for the hypothesis of Mendelian segregation 1:2:1 (RR:RS:SS). The segregation analysis of the disease reaction of $F_{2}$ populations from each cross $(R \times R)$ were conducted using the chi-square test of goodness-of-fit to the hypothesis of Mendelian segregation 15:1 (R:S) for two independent genes.

The SNP markers were used to map the resistance gene in Paloma using DNA of the $F_{2}$ plants from Paloma $\times$ PI 207262 cross. Genetic distances between the SNP markers and the new anthracnose resistance gene in Paloma was estimated using software JoinMap
4.0 [44]. Default settings of Regression Mapping algorithm based on the Kosambi map function were attributed to define the linkage order and distances in centimorgans (cM). A minimum likelihood of odds (LOD) $\geq 3.0$ and a maximum distance of $\leq 50 \mathrm{cM}$ were used to test linkages among markers. Genetic linkage map, containing the genetic distances between SNP markers and the anthracnose resistance gene in Paloma, was drawn using the software MapChart [45]. The SNP markers flanking the anthracnose resistance locus in Paloma were used to determine the physical region of the new locus. Candidate annotated genes in the region were identified by inspecting the genome browser from the reference genome of common bean in phytozome.org [5].

\section{Results}

Phenotypic reaction of cultivar Paloma and other Andean cultivars

Table 1 shows the disease reaction of Paloma and the other anthracnose resistance Andean cultivars, when inoculated with C. lindemuthianum Andean races (2, 7, 19, 23 and 55) and Mesoamerican races $(65,73,89,449$, 453, 1545, 2047 and 3481). Paloma was resistant to Andean races 23 and 55, as well as to Mesoamerican races 65, 73, 1545, 2047 and 3481.

\section{Inheritance of anthracnose resistance in Paloma}

The inheritance of resistance study conducted with $99 \mathrm{~F}_{2}$ plants from the cross between Paloma (resistant) $x$ Cornell 49-242 (susceptible), inoculated with C. lindemuthianum race 2047, exhibited a segregation pattern

Table 1 Reaction of Andean common bean cultivars to various races of Colletotrichum lindemuthianum

\begin{tabular}{|c|c|c|c|c|c|c|c|c|c|c|c|c|c|c|c|}
\hline \multirow[t]{2}{*}{ Cultivar } & \multirow[t]{2}{*}{ Gene } & \multirow{2}{*}{$\begin{array}{l}\text { Linkage } \\
\text { group }\end{array}$} & \multicolumn{13}{|c|}{ Reaction to C. lindemuthianum races } \\
\hline & & & 2 & 7 & 19 & 23 & 55 & 65 & 73 & 89 & 449 & 453 & 1545 & 2047 & 3481 \\
\hline Paloma & $\mathrm{Co}-\mathrm{Pa}$ & Pv01 & $\mathrm{S}^{\mathrm{e}}$ & S & S & $\mathrm{R}$ & R & $\mathrm{R}$ & $\mathrm{R}$ & S & S & S & R & R & $\bar{R}$ \\
\hline MDRK $^{\mathrm{a}}$ & $\mathrm{Co}^{-1}$ & Pv01 & S & S & S & S & S & $\mathrm{R}$ & $R$ & R & $\mathrm{R}$ & $\mathrm{R}$ & $\mathrm{R}$ & S & $\mathrm{R}$ \\
\hline Kaboon & $\mathrm{CO}^{-} \mathrm{1}^{2}$ & Pv01 & $R^{f}$ & $\mathrm{R}$ & $\mathrm{R}$ & $\mathrm{R}$ & S & $\mathrm{R}$ & $\mathrm{R}$ & $\mathrm{R}$ & $\mathrm{R}$ & $\mathrm{R}$ & $\mathrm{R}$ & S & $\mathrm{R}$ \\
\hline $\mathrm{PM}^{\mathrm{b}}$ & $\mathrm{CO}^{3} 1^{3}$ & Pv01 & $\mathrm{R}$ & S & R & S & S & $\mathrm{R}$ & $\mathrm{R}$ & $\mathrm{R}$ & $\mathrm{R}$ & S & $\mathrm{R}$ & S & $\mathrm{R}$ \\
\hline AND 277 & $\mathrm{CO}^{-1}{ }^{4}$ & Pv01 & $N A^{9}$ & NA & S & R & R & R & $\mathrm{R}$ & R & NA & R & R & R & $\mathrm{R}$ \\
\hline Widusa & $\mathrm{CO}_{-1}{ }^{5}$ & Pv01 & $\mathrm{R}$ & $\mathrm{R}$ & S & S & S & $\mathrm{R}$ & $\mathrm{R}$ & S & $\mathrm{R}$ & $\mathrm{R}$ & $\mathrm{R}$ & S & $S$ \\
\hline$J V^{c}$ & $\mathrm{Co}-12$ & - & NA & S & S & $R$ & R & R & S & R & $\mathrm{R}$ & $R$ & R & S & S \\
\hline$J P^{d}$ & $\mathrm{Co}-13$ & Pv03 & NA & S & S & S & S & $\mathrm{R}$ & $\mathrm{R}$ & R & S & S & $\mathrm{R}$ & S & $\mathrm{R}$ \\
\hline Pitanga & $\mathrm{Co}-14$ & Pv01 & NA & NA & R & R & R & R & R & S & NA & S & S & R & S \\
\hline Corinthiano & Co-15 & Pv04 & R & NA & S & $\mathrm{R}$ & S & R & $\mathrm{R}$ & R & R & S & $\mathrm{R}$ & R & S \\
\hline Jalo EEP558 & $\begin{array}{l}\text { Co-w } \\
\text { Co-x } \\
\text { Co-y } \\
\text { Co-z }\end{array}$ & $\begin{array}{l}\text { Pv01 } \\
\text { Pv04 }\end{array}$ & S & S & S & NA & S & $\mathrm{R}$ & $\mathrm{R}$ & S & R & R & $\mathrm{R}$ & S & NA \\
\hline
\end{tabular}


fitted in a 3R:1S ratio $\left(\chi^{2}=0.084 ; p=0.77\right)$, showing that resistance in Paloma to race 2047 is conferred by a dominant gene. The inheritance of resistance of $90 \mathrm{~F}_{2}$ plants from the Paloma (resistant) $\times$ PI 207262 (susceptible) cross, inoculated with race 3481, resulted in a segregation that fitted a ratio of 3R:1S. Similarly, the segregation of the $73 \mathrm{~F}_{2: 3}$ families from the Paloma (resistant) $\times$ PI 207262 (susceptible) cross, inoculated with race 3481, fitted a ratio of 1RR:2RS:1SS. This fact suggested that a single dominant gene in Paloma confers resistance to race 3481 of C. lindemuthianum (Table 2).

\section{Allelism tests}

Genetic analysis of $F_{2}$ populations involving parental cultivars with resistant reactions to various races of the anthracnose pathogen showed that the resistance gene in Paloma is independent from previously characterized anthracnose resistance genes (Table 3). The allelism tests for the $F_{2}$ populations derived from crosses between cultivar Paloma with the common bean cultivars MDRK, Cornell 49-242, Ouro Negro, TO, G 2333, PI 207262, TU, and AB 136 showed a 15:1 segregation ratio in each population, indicating that two dominant genes conferred resistance to anthracnose.

Segregations observed in the $F_{2}$ populations of crosses of Paloma with the cultivars Jalo Vermelho $(p$ $=0.96)$, Jalo Listras Pretas $(p=0.81)$, Pitanga $(p=$ $0.89)$, Corinthiano $(p=0.92)$, Crioulo $159(p=0.92)$, Perla $(p=0.57)$, Amendoim Cavalo $(p=0.92)$, and Jalo Pintado $2(p=0.99)$ also exhibited a 15R:1S ratio. These results demonstrated the independence of the dominant gene present in Paloma from previously characterized anthracnose resistance genes shown on Table 3. Thus, the gene in Paloma is independent from $\mathrm{Co}-1, \mathrm{Co}-2, \mathrm{Co}-3^{4}, \mathrm{Co}-4, \mathrm{Co}-4^{2}, \mathrm{Co}-4^{3}, \mathrm{Co}-5, \mathrm{Co}-$ 6, Co-12, Co-13, Co-14, Co-15 and Co-16, as well as from unnamed resistance genes in common bean cultivars Perla, Amendoim Cavalo and Jalo Pintado 2.
BSA and SNP genotyping using BARCBEAN6K_3 BeadChip Table 4 displays the 33 genotyped SNPs on the resistant and susceptible bulks constructed using DNA of the $\mathrm{F}_{2}$ individuals derived from the Paloma $\times$ PI 207262 cross. These SNPs were positively associated with the new Andean gene $\mathrm{Co}-\mathrm{Pa}$ present in Paloma. All positive SNP markers were positioned spanning a $2.779 \mathrm{Mb}$ region of the lower arm of chromosome Pv01. The SNPs were positioned in a region between 60.170 and $75.989 \mathrm{cM}$ on the common bean chromosome Pv01, using the linkage map presented by Song et al. [41]. The region containing $\mathrm{Co}-\mathrm{Pa}$ was flanked by SNP markers ss715645931 (48,838,736 bp) and ss715645293 (51,617,802 bp).

\section{KASP assay development and gene mapping}

Nine positive SNPs, distributed in the candidate physical region, were selected for the development of KASP assays to genotype the $73 \quad F_{2}$ plants from the cross Paloma $\times$ PI 207262 (Table 5). The phenotypic evaluations carried out in the corresponding $\mathrm{F}_{2: 3}$ families were combined with the SNP genotyping of the $\mathrm{F}_{2}$ population. A total of six $F_{2}$ plants revealed breakpoints, suggesting that the Andean anthracnose resistance gene in Paloma is flanked by markers SS82 (50,546,985 bp) and SS83 $(50,155,987 \mathrm{bp})$, spanning a 390,998 bp region of chromosome Pv01 (Additional file 1: Table S1). The mapping analysis of these SNP markers associated with the $73 \mathrm{~F}_{2}$ plants of Paloma $\times$ PI 207262 cross demonstrated that the resistance locus to $C$. lindemuthianum of Paloma is located between the markers SS82 and SS83 at a distance of 2.6 and $2.0 \mathrm{cM}$, respectively (Fig. 1a).

In order to obtain more experimental precision, the three SNP markers, which are very close linked to $\mathrm{Co}^{-}$ $\mathrm{Pa}$, were carefully chosen for genotyping the $163 \mathrm{~F}_{2}$ plants from Paloma $\times$ PI 207262 cross, involving the same $73 \mathrm{~F}_{2}$ individuals previously genotyped and a new set of $90 \mathrm{~F}_{2}$ plants (Additional file 2: Table S2). For that, all these plants had their phenotypic reaction evaluated

Table $\mathbf{2}$ Inheritance of anthracnose resistance in the common bean cultivar Paloma

\begin{tabular}{|c|c|c|c|c|c|}
\hline Crosses & Generation & Observed ratio & Expected ratio & $x^{2}$ & $P$-value \\
\hline \multicolumn{6}{|c|}{ Race 2047 of Colletotrichum lindemuthianum } \\
\hline Paloma & $\mathrm{RP}^{\mathrm{a}}$ & 10:0 & & & \\
\hline Cornell 49-242 & $S P^{b}$ & $0: 10$ & & & \\
\hline Paloma $\times$ Cornell 49-242 & $\mathrm{F}_{2}$ & $73: 26$ & $74.25 R^{c}: 24.75 S^{d}$ & 0.084 & 0.77 \\
\hline \multicolumn{6}{|c|}{ Race 3481 of Colletotrichum lindemuthianum } \\
\hline Paloma & RP & $10: 0$ & & & \\
\hline PI 207262 & SP & $0: 10$ & & & \\
\hline Paloma × PI 207262 & $\mathrm{~F}_{2}$ & $65: 25$ & 67.50R:22.50S & 0.370 & 0.54 \\
\hline Paloma × PI 207262 & $\mathrm{~F}_{2: 3}$ & $12: 43: 18$ & 18.25RR:36.52RS:18.25SS & 3.301 & 0.19 \\
\hline
\end{tabular}

${ }^{\mathrm{a}}$ Resistant Parent; ${ }^{\mathrm{b}}$ Susceptible Parent; ${ }^{\mathrm{c}}$ Resistant; ${ }^{\mathrm{d}}$ Susceptible 
Table 3 Allelism tests for the anthracnose resistance gene in the common bean cultivar Paloma

\begin{tabular}{|c|c|c|c|c|c|c|c|c|}
\hline \multirow[t]{2}{*}{ Crosses } & \multirow{2}{*}{$\begin{array}{l}\text { Resistance } \\
\text { Gene }\end{array}$} & \multirow[t]{2}{*}{ Race } & \multirow{2}{*}{$\begin{array}{l}\text { Linkage } \\
\text { Group }\end{array}$} & \multicolumn{2}{|c|}{ Observed Ratio } & \multirow{2}{*}{$\begin{array}{l}\text { Expected } \\
\text { Ratio (R:S) }\end{array}$} & \multirow[t]{2}{*}{$x^{2}$} & \multirow{2}{*}{$\begin{array}{l}P \text { - } \\
\text { value }\end{array}$} \\
\hline & & & & $\overline{R^{d}}$ & $S^{e}$ & & & \\
\hline Paloma $\times$ MDRK $^{a}$ & $\mathrm{Co}^{-1}$ & 73 & Pv01 & 92 & 8 & $15: 1$ & 0.523 & 0.47 \\
\hline Paloma × Cornell 49-242 & Co-2 & 65 & Pv11 & 84 & 6 & $15: 1$ & 0.027 & 0.87 \\
\hline Paloma $\times$ Ouro Negro & $\mathrm{CO}^{-} 3^{4}$ & 73 & Pv04 & 118 & 9 & $15: 1$ & 0.152 & 0.70 \\
\hline Paloma ×TO & Co-4 & 65 & Pv08 & 111 & 8 & $15: 1$ & 0.045 & 0.83 \\
\hline Paloma $\times$ G 2333 & $\mathrm{CO}-4^{2}$ & 2047 & Pv08 & 155 & 13 & $15: 1$ & 0.635 & 0.43 \\
\hline Paloma × PI 207262 & $\mathrm{CO}-4^{3}$ & 65 & Pv08 & 137 & 10 & $15: 1$ & 0.076 & 0.78 \\
\hline Paloma ×TU & Co-5 & 65 & 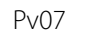 & 109 & 6 & $15: 1$ & 0.209 & 0.65 \\
\hline Paloma × AB 136 & Co-6 & 65 & Pv07 & 106 & 8 & $15: 1$ & 0.114 & 0.73 \\
\hline Paloma × Jalo Vermelho & $\mathrm{Co}-12$ & 65 & - & 107 & 7 & $15: 1$ & 0.002 & 0.96 \\
\hline Paloma $\times J\left\llcorner P^{b}\right.$ & $\mathrm{Co}-13$ & 65 & Pv03 & 110 & 8 & $15: 1$ & 0.056 & 0.81 \\
\hline Paloma $\times$ Pitanga & $\mathrm{CO}-14$ & 73 & Pv01 & 56 & 4 & $15: 1$ & 0.018 & 0.89 \\
\hline Paloma × Corinthiano & Co-15 & 2047 & Pv04 & 94 & 6 & $15: 1$ & 0.011 & 0.92 \\
\hline Paloma × Crioulo 159 & Co-16 & 2047 & Pv04 & 94 & 6 & $15: 1$ & 0.011 & 0.92 \\
\hline Paloma $\times$ Perla & - & 65 & - & 111 & 19 & $15: 1$ & 0.320 & 0.57 \\
\hline Paloma $\times \mathrm{AC}^{\mathrm{C}}$ & - & 2047 & - & 109 & 7 & $15: 1$ & 0.009 & 0.92 \\
\hline Paloma $\times$ Jalo Pintado 2 & - & 2047 & - & 90 & 6 & $15: 1$ & 0.001 & 0.99 \\
\hline
\end{tabular}

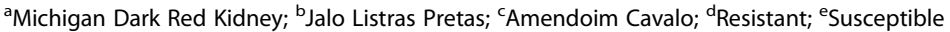

using the race 3481 of the $C$. lindemuthianum. These results revealed that the anthracnose resistance gene $\mathrm{Co}-\mathrm{Pa}$ of Paloma is located between SS82 and SS83 markers at the distance of 1.3 and $2.1 \mathrm{cM}$, respectively. Additionally, the SNP marker SS83 effectively differentiated homozygous resistant, homozygous susceptible and heterozygous individuals (Fig. 2).

\section{The Co-Pa gene of Paloma mapping to a cluster of disease resistance genes}

Based on the gene annotation for the $P$. vulgaris genome V1.0 (phytozome.org), the $\sim 390 \mathrm{Kbp}$ genomic region, containing the anthracnose resistance locus from Paloma, has 46 annotated genes. Most of these genes encode proteins with predicted functions unrelated to plant pathogen defense. However, nine genes contain domains with known function related to pathogen resistance response in plants [5]. These genes are: Phvul.001G243100, Phvul.001G243200 and Phvul.001G243300 encoding phosphoinositide-specific phospholipase-C (PI-PLC) proteins. Genes Phvul.001G243 500, Phvul.001G243600, Phvul.001G243700, Phvul.001G24. 3800 and Phvul.001G245100 encode serine threonine protein kinase (STK), while Phvul.001G245300 encodes leucine-rich repeat (LRR) with a protein tyrosine kinase (PTK) domain.

\section{Discussion}

A broad genetic base is essential for the protection of crops, especially for their protection against pathogens with high virulence diversity. The utilization of Andean common bean for the genetic improvement of the common bean crop has lagged far behind the use of Mesoamerican common bean [6]. Paradoxically, the underutilized genetic diversity of Andean common bean contains genes conferring effective resistance to highly virulent Mesoamerican races of the pathogens that cause anthracnose, angular leaf spot, and rust diseases of common bean [10, 37, 46]. Incorporating Andean anthracnose resistance genes, such as the new gene $(\mathrm{Co}-\mathrm{Pa})$ in Paloma in common bean-breeding programs, would make possible the development of common bean cultivars with broad resistance to $C$. lindemuthianum.

The results of this study showed that the Andean cultivar Paloma is a very important source of anthracnose resistance, particularly for the protection against Mesoamerican races of this pathogen. We observed that Paloma was resistant to $C$. lindemuthianum Andean races 23 and 55 and to Mesoamerican races 65, 73, 1545, 2047 and 3481. Interestingly, Paloma as shown to be effective against Mesoamerican races of the anthracnose pathogen that are frequent in countries such as: United States, Brazil and Central America. The resistance of Paloma to races 23, 55, 65 and 73 has a great importance for common bean breeding programs in Brazil, especially on places where these races are widespread [47]. Race 73 is present in 13 of the 14 states of Brazil, while race 65 is present in 12 states of this country [9]. Race 65 has also been reported in Honduras, Mexico, USA, Costa Rica, Guatemala, Puerto Rico, India 
Table 4 SNP markers associated with the resistant gene in Paloma discovered by BSA

\begin{tabular}{|c|c|c|c|}
\hline BARCBEAN6K_3 SNP ID & NCBI ss\# id & Genetic distance $(\mathrm{cM})^{\mathrm{a}}$ & Physical position (bp) \\
\hline BARCPV_1.0_Chr01_48838736_G_A & ss715645931 & 60.170 & $48,838,736$ \\
\hline BARCPV_1.0_Chr01_48865391_A_G & ss715645929 & 60.170 & $48,865,391$ \\
\hline BARCPV_1.0_Chr01_48925715_G_A & ss715645922 & 60.767 & $48,925,715$ \\
\hline BARCPV_1.0_Chr01_48985087_G_A & ss715645915 & 60.963 & $48,985,087$ \\
\hline BARCPV_1.0_Chr01_48993566_T_C & ss715645914 & 60.963 & $48,993,566$ \\
\hline BARCPV_1.0_Chr01_49001931_C_T & ss715645913 & 60.963 & $49,001,931$ \\
\hline BARCPV_1.0_Chr01_49030363_T_G & ss715645911 & 60.963 & $49,030,363$ \\
\hline BARCPV_1.0_Chr01_49102396_T_C & ss715645906 & - & $49,102,396$ \\
\hline BARCPV_1.0_Chr01_49112768_C_A & ss715645904 & 61.543 & $49,112,768$ \\
\hline BARCPV_1.0_Chr01_49123029_C_T & ss715645903 & - & $49,123,029$ \\
\hline BARCPV_1.0_Chr01_49181319_T_C & ss715645900 & 61.920 & $49,181,319$ \\
\hline BARCPV_1.0_Chr01_49192664_G_A & ss715645899 & 62.445 & $49,192,664$ \\
\hline BARCPV_1.0_Chr01_49261257_G_A & ss715645892 & 62.034 & $49,261,257$ \\
\hline BARCPV_1.0_Chr01_49329790_T_C & ss715645883 & 62.834 & $49,329,790$ \\
\hline BARCPV_1.0_Chr01_49361978_A_C & ss715645881 & 62.834 & $49,361,978$ \\
\hline BARCPV_1.0_Chr01_49487812_C_T & ss715645868 & 63.341 & $49,487,812$ \\
\hline BARCPV_1.0_Chr01_49517944_C_T & ss715645866 & 63.341 & $49,517,944$ \\
\hline BARCPV_1.0_Chr01_49531622_G_A & ss715645864 & 63.341 & $49,531,622$ \\
\hline BARCPV_1.0_Chr01_49546017_T_C & ss715645861 & 63.341 & $49,546,017$ \\
\hline BARCPV_1.0_Chr01_49588715_A_G & ss715645859 & 63.933 & $49,588,715$ \\
\hline BARCPV_1.0_Chr01_49606339_T_C & ss715645857 & 64.862 & $49,606,339$ \\
\hline BARCPV_1.0_Chr01_49617274_G_A & ss715645856 & 63.933 & $49,617,274$ \\
\hline BARCPV_1.0_Chr01_49637944_C_A & ss715645853 & 63.933 & $49,637,944$ \\
\hline BARCPV_1.0_Chr01_49657760_C_T & ss715645852 & 63.933 & $49,657,760$ \\
\hline BARCPV_1.0_Chr01_49671031_G_A & ss715645935 & 64.122 & $49,671,031$ \\
\hline BARCPV_1.0_Chr01_49678615_G_A & ss715645927 & 64.122 & $49,678,615$ \\
\hline BARCPV_1.0_Chr01_49694647_G_A & ss715645910 & 64.493 & $49,694,647$ \\
\hline BARCPV_1.0_Chr01_49742126_G_A & ss715645862 & 64.648 & $49,742,126$ \\
\hline BARCPV_1.0_Chr01_49749711_T_C & ss715645855 & 64.648 & $49,749,711$ \\
\hline BARCPV_1.0_Chr01_49841858_G_A & ss715645286 & 65.168 & $49,841,858$ \\
\hline BARCPV_1.0_Chr01_50155987_T_C & ss715645258 & 66.999 & $50,155,987$ \\
\hline BARCPV_1.0_Chr01_50203547_C_T & ss715645254 & 67.201 & $50,203,547$ \\
\hline BARCPV_1.0_Chr01_50546985_T_C & ss715645248 & - & $50,54,6985$ \\
\hline BARCPV_1.0_Chr01_51289521_C_A & ss715645302 & 75.989 & $51,289,521$ \\
\hline BARCPV_1.0_Chr01_51353193_C_T & ss715645299 & - & $51,353,193$ \\
\hline BARCPV_1.0_Chr01_51617802_G_A & ss715645293 & - & $51,61,7802$ \\
\hline
\end{tabular}

a Linkage position (cM) on Pv01 of markers in the Stampede $\times$ Red Hawk $(S \times R) F_{2}$ population [41]

and Canada [9]. Among the resistance genes in Andean cultivars, $\mathrm{Co}-1^{4}, \mathrm{Co}-12$ and $\mathrm{Co}-14$ are resistant to Andean race 55 . This race overcomes the resistance of the Andean $\mathrm{Co}-1, \mathrm{Co}-1^{2}, \mathrm{Co}-1^{3}, \mathrm{Co}-1^{5}, \mathrm{Co}-13$ and $\mathrm{Co}-15$ resistant genes. Race 55 also overcomes the resistance of Andean common bean Jalo EEP558, which contains the Co-w, Co- $x$, Co-y and Co- $z$ anthracnose resistant genes.
Paloma is also resistant to the highly virulent Mesoamerican races 2047 and 3481. Race 2047 is virulent on 11 of the 12 differential cultivars. Thus, this race overcomes the resistance of the $\mathrm{Co}-1$ and four of its alleles, $\mathrm{Co}-2, \mathrm{Co}-3$, some of the alleles of $\mathrm{Co}-4, \mathrm{Co}-5, \mathrm{Co}-6, \mathrm{Co}-$ 11, Co-12, Co-13, and the four anthracnose genes present in Jalo EEP 558. G 2333 was the only differential 
Table 5 KASP primers associated with the resistant gene in Paloma

\begin{tabular}{|c|c|c|c|c|}
\hline SNP id & NCBI ss\# id & $\begin{array}{l}\text { Physical position } \\
(\mathrm{bp})^{\mathrm{a}}\end{array}$ & BARCBEAN6K_3 SNP ID & Primers sequences $b, c, d$ \\
\hline SS75 & ss715645931 & 48838736 & BARCPV_1.0_Chr01_48838736_G_A & $\begin{array}{l}\text { F1: GAAGGTGACCAAGTTCATGCTGTGTTATGTGTAGATATATTGA } \\
\text { AAGGC } \\
\text { F2: GAAGGTCGGAGTCAACGGATTACTGTGTTATGTGTAGATATATTGA } \\
\text { AAGGT } \\
\text { R: TGATCTCTTAATGGGAGGTTTGTGCTT }\end{array}$ \\
\hline SS76 & ss715645913 & 49001931 & BARCPV_1.0_Chr01_49001931_C_T & $\begin{array}{l}\text { F1: GAAGGTGACCAAGTTCATGCTCAGCTTCTACCCGTGGCTGC } \\
\text { F2: GAAGGTCGGAGTCAACGGATTGCAGCTTCTACCCGTGGCTGT } \\
\text { R: GTCGCTTCTAGTTGTCTTIAATTATCTTAT }\end{array}$ \\
\hline SS77 & ss715645900 & 49181319 & BARCPV_1.0_Chr01_49181319_T_C & $\begin{array}{l}\text { F1: GAAGGTGACCAAGTTCATGCTCAGTTGAACATTATGTTACAGAC } \\
\text { TACTIT } \\
\text { F2: GAAGGTCGGAGTCAACGGATTCAGTTGAACATTATGTTACAGA } \\
\text { CTACTTC } \\
\text { R: AAACCTAAACTAATAACAAAATTTATGTAT }\end{array}$ \\
\hline SS78 & ss715645883 & 49329790 & BARCPV_1.0_Chr01_49329790_T_C & $\begin{array}{l}\text { F1: GAAGGTGACCAAGTTCATGCTATTAGGCTGTTCAAGCTITCCAGGT } \\
\text { F2: GAAGGTCGGAGTCAACGGATTAGGCTGTTCAAGCTITCCAGGC } \\
\text { R: CACCCCAATTACATITCTCTITATGAATT }\end{array}$ \\
\hline SS79 & ss715645868 & 49487812 & BARCPV_1.0_Chr01_49487812_C_T & $\begin{array}{l}\text { F1: GAAGGTGACCAAGTTCATGCTGCCGCTGGTGAAGATGAATACC } \\
\text { F2: GAAGGTCGGAGTCAACGGATTCGCCGCTGGTGAAGATGAATACT } \\
\text { R: CGTGTATGCGACCCGGTCGAA }\end{array}$ \\
\hline SS80 & ss715645856 & 49617274 & BARCPV_1.0_Chr01_49617274_G_A & $\begin{array}{l}\text { F1: GAAGGTGACCAAGTTCATGCTATATTTGTTATTATGGTGTCATCA } \\
\text { TATCTTAA } \\
\text { F2: GAAGGTCGGAGTCAACGGATTATATTTGTATTATGGTGTCAT } \\
\text { CATATCTTAAT } \\
\text { R: GTTTGAACTGATGTAATAACTGAACCTATA }\end{array}$ \\
\hline SS81 & ss715645862 & 49742126 & BARCPV_1.0_Chr01_49742126_G_A & $\begin{array}{l}\text { F1: GAAGGTGACCAAGTTCATGCTATTGAAGATAAGTACTATCGATGA } \\
\text { TATCAG } \\
\text { F2: GAAGGTCGGAGTCAACGGATTGTATTGAAGATAAGTACTATCG } \\
\text { ATGATATCAA } \\
\text { R: GTGAGGTAGTTCGATCCTCTTGAGAT }\end{array}$ \\
\hline SS82 & ss715645258 & 50155987 & BARCPV_1.0_Chr01_50155987_T_C & $\begin{array}{l}\text { F1: GAAGGTGACCAAGTTCATGCTAAAACCAGGTTTATTGTCCTAGTT } \\
\text { TACAA } \\
\text { F2: GAAGGTCGGAGTCAACGGATTAACCAGGTTTATTGTCCTAGTT } \\
\text { TACAG } \\
\text { R: GTATCTCATCTTGTTGCAAGAGTGAATATA }\end{array}$ \\
\hline SS83 & ss715645248 & 50546985 & BARCPV_1.0_Chr01_50546985_T_C & $\begin{array}{l}\text { F1: GAAGGTGACCAAGTTCATGCTCATATACTTTCTGGGTGTAAAC } \\
\text { TCTGA } \\
\text { F2: GAAGGTCGGAGTCAACGGATTATATACTTTCTGGGTGTAAA } \\
\text { CTCTGG } \\
\text { R: CCCAGGTGTTCTGGTCATGAGTTAT }\end{array}$ \\
\hline
\end{tabular}

${ }^{\text {a }}$ Physical position of SNP in the common bean reference genome v1.0; ${ }^{b} \mathrm{~F} 1$ : Forward $1 ;{ }^{\mathrm{C}} \mathrm{F} 2$ : Forward $2,{ }^{\mathrm{d}} \mathrm{R}$ : Reverse

cultivar that was resistant to race 2047. Among the Andean anthracnose resistance genes, only Co-14, Co- 15 and $\mathrm{Co}-1^{4}$ were resistant to race 2047 . Similarly, race 3481 overcomes the resistance of seven of the 12 differential cultivars, including G 2333 that contains the Co$3^{5}, \mathrm{Co}-4^{2}$ and $\mathrm{Co}-5^{2}$ alleles. Andean alleles $\mathrm{Co}-1, \mathrm{Co}-\mathrm{I}^{2}$, $\mathrm{Co}-1^{3}, \mathrm{Co}-1^{4}$, and gene $\mathrm{Co}-13$ were resistant to race 3481. Therefore, only AND $\left.277\left(\mathrm{Co}^{-1}\right)^{4}\right)$ and Paloma $(\mathrm{Co}-\mathrm{Pa})$ were resistant to the highly virulent 2047 and 3481 races of $C$. lindemuthianum.

The inheritance of resistance evaluation from the cross Paloma $(\mathrm{R}) \times$ Cornell 49-242 (S) - inoculated with race 2047, and the cross Paloma (R) $\times$ PI 207262 (S) - inoculated with race 3481, revealed the presence of a single dominant gene in Paloma. Furthermore, bulk segregant analysis, using the BARCBean6K_3 BeadChip in common bean, positioned the resistance gene in Paloma $(\mathrm{Co}-\mathrm{Pa})$ in the lower arm of chromosome Pv01 where other anthracnose resistant genes have been mapped. These genes include $\mathrm{Co}-1$ and its alleles, Co-14, Co- $x$ and $\mathrm{Co}-w$. The allelism tests showed that $\mathrm{Co}-\mathrm{Pa}$ is independent from the allelic series $\mathrm{Co}-1$ and the $\mathrm{Co}-14$ genes. No allelism test was conducted with Jalo EEP558, which contains two anthracnose resistant genes $(\mathrm{Co}-\mathrm{x}$ and $C o-w)$ in Pv01. However, the anthracnose resistant phenotype of Paloma and Jalo EEP558 were different for races 55, 449, 453, and 2047, suggesting that $\mathrm{Co}-\mathrm{Pa}$ may be different from Co- $x$ and $\mathrm{Co}-w$ (Table 1).

The Co-Pa anthracnose resistant gene in Paloma is mapped to a cluster containing anthracnose $(\mathrm{Co}-1$ and its alleles, Co-14, Co- $x, C o-w)$, rust (Ur-9) and angular leaf spot (Phg-1) disease resistant genes [21, 48-50]. 


\section{Pv01}

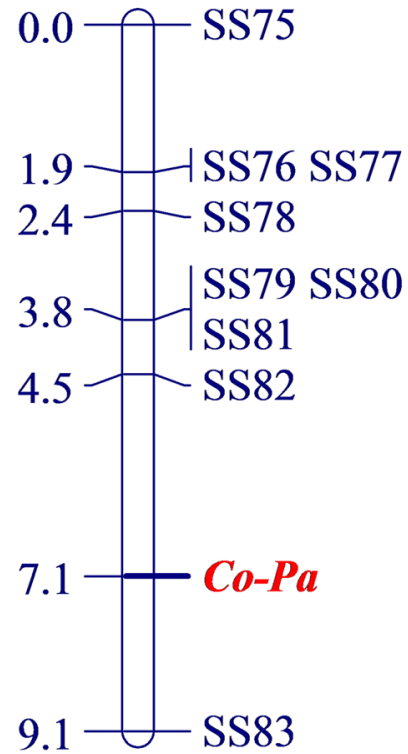

a

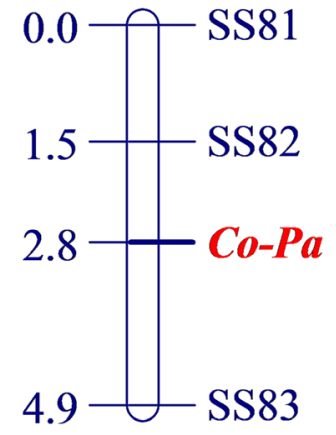

b
Fig. 1 Genetic linkage map of the SNP markers and anthracnose resistance gene in Paloma. a Linkage group Pv01 for the Co-Pa in Paloma and nine SNP markers genotyped in $73 \mathrm{~F}_{2}$ plants of Paloma X PI 207262; b Linkage group Pv01 for the Co-Pa and three close linked SNP markers genotyped in $163 \mathrm{~F}_{2}$ individuals of Paloma $\times$ PI 207262
Dense clusters of tightly linked resistance-associated genes in the common bean genome encode mostly NBLRR (nucleotide-binding, leucine-rich repeat) genes [5]. The identification of this protein class across diverse plant species demonstrated that NB-LRR genes are a pillar of plant defense [51]. NB-LRR gene clusters enriched with an N-terminal coiled-coil domain (CNL) or an $\mathrm{N}$ terminal Toll-interleukin-1 receptor (TIR)-like domain (TNL) were identified at the ends of common bean chromosomes, such as the distal part of Pv01 [5, 23]. It is worth noting that all resistance genes currently mapped on chromosome Pv01 are from common bean of Andean origin. This is a unique situation among the chromosomes of common bean containing disease resistance genes.

The combined results of SS82 and SS83 SNP markers, with the monogenic inheritance and allelism tests, confirmed the hypothesis that a single dominant gene confers resistance to C. lindemuthianum races 65, 73, 2047 and 3481 in the Andean common bean cultivar Paloma. Likewise, this gene is independent from those common bean anthracnose resistance genes previously characterized. The authors propose that this single dominant anthracnose resistance gene in Paloma to be temporarily named as $\mathrm{Co}-\mathrm{Pa}$, until a new designation is defined by the Genetics Committee of the Bean Improvement Cooperative.

Future efforts will focus on fine mapping of the 390,998 bp region in Pv01 containing the Co-Pa, the resistance gene in Paloma. Co- $x$ and $\mathrm{Co}^{-1} \mathrm{I}^{4}$ anthracnose resistance genes have been closely mapped to $\mathrm{Co}-\mathrm{Pa}$. Thus, genetic analysis of segregating populations from the cross between Paloma and cultivars containing $\mathrm{Co}^{-1} \mathrm{I}^{4}$ and $\mathrm{Co-x}$ will be the subject of future studies.

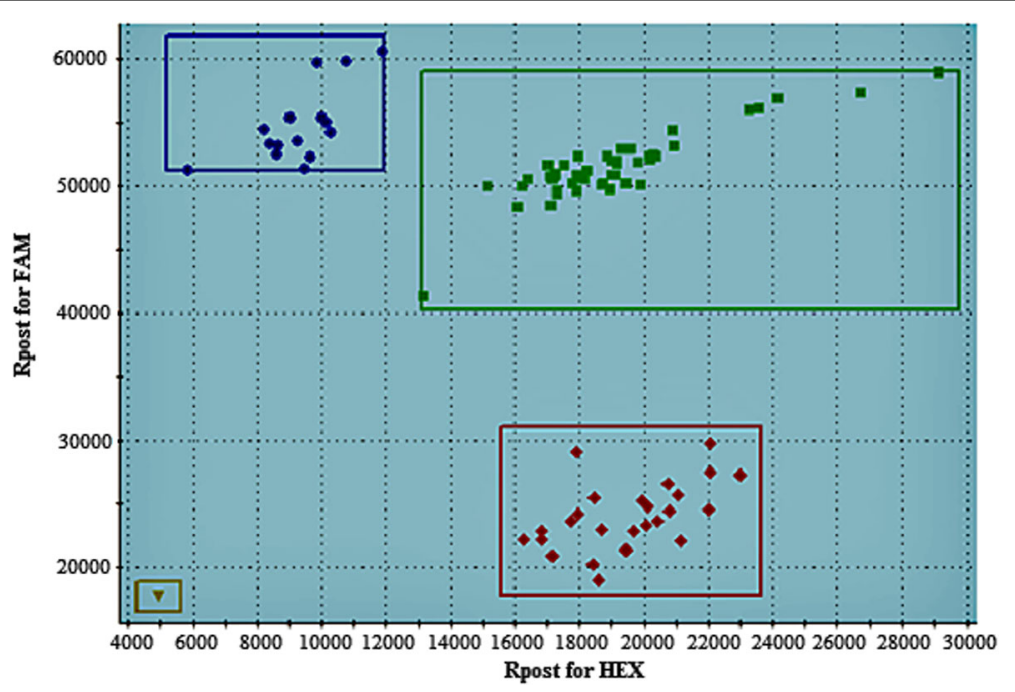

Fig. 2 A SNP marker display. Clustering of the 73 F individuals from Paloma $\times$ PI 207262 cross: Paloma allele (blue), PI 207262 allele (red) and heterozygous allele (green) for the SS83 SNP marker 
The $\mathrm{Co}-\mathrm{Pa}$ anthracnose resistant gene in Paloma provides resistance to the Mesoamerican races 2047 and 3481 of $C$. lindemuthianum that overcome the most of known resistance genes in common bean. Furthermore, the $\mathrm{Co}-\mathrm{Pa}$ gene in Paloma confers resistance to these and many other Mesoamerican races. On the other hand, the Mesoamerican genes $\mathrm{Co}^{-} 4$ and its alleles, $\mathrm{Co}-5$, Co-6 and other anthracnose Mesoamerican resistant genes confer effective resistance to Andean races that overcome the resistance of $\mathrm{Co}-\mathrm{Pa}$ and other Andean resistance genes.

These results suggest that combining $\mathrm{Co}-\mathrm{Pa}$ with $\mathrm{Me}$ soamerican resistant genes in a single cultivar will confer effective and possibly durable resistance to all known races of the highly variable anthracnose pathogen of common bean. In addition, the flanking SNP markers SS82 and SS83 linked to resistance gene $\mathrm{Co}-\mathrm{Pa}$ of Paloma, will be very useful for gene pyramiding of $\mathrm{Co}-\mathrm{Pa}$ with other Mesoamerican and Andean genes.

\section{Conclusions}

The results presented here showed that Paloma cultivar has a new dominant gene conferring resistance to anthracnose, which is independent from the $\mathrm{Co}-1, \mathrm{Co}-2$, $\mathrm{Co}$ $3^{4}, \mathrm{Co}-4, \mathrm{Co}-4^{2}, \mathrm{Co}-4^{3}, \mathrm{Co}-5, \mathrm{Co}-6, \mathrm{Co}-12, \mathrm{Co}-13, \mathrm{Co}-14$, $\mathrm{Co}-15$ and $\mathrm{Co}-16$ genes, previously described. This gene, provisionally named as $\mathrm{Co}-\mathrm{Pa}$ gene in Paloma, was mapped on the chromosome Pv01 of common bean at $390 \mathrm{~kb}$ region, flanked by SNP markers SS82 and SS83. The linkage between these markers and the $\mathrm{Co}-\mathrm{Pa}$ gene will be extremely important for marker-assisted introgression of the gene into elite cultivars in order to enhance resistance.

\section{Additional files}

Additional file 1: Table S1. Phenotypic evaluation of the $73 F_{2: 3}$ families of the Paloma $\times$ PI 207262 cross inoculated with the Colletotrichum lindemuthianum race 3481 and genotyping of the corresponding $F_{2}$ plants with nine KASP markers associated with the anthracnose resistance gene in Paloma. (XLSX 14 kb)

Additional file 2: Table S2. Phenotypic evaluation of the $90 \mathrm{~F}_{2}$ plants of the Paloma XPI 207262 cross inoculated with the Colletotrichum lindemuthianum race 3481 and genotyping with three KASP markers close linked to the anthracnose resistance gene in Paloma. (XLSX $13 \mathrm{~kb})$

\section{Abbreviations}

ARS: Agricultural research service; BSA: Bulk segregant analysis; CNL: $\mathrm{N}$-terminal coiled-coil domain; INTA: Instituto Nacional de Tecnología Agropecuaria; KASP: Kompetitive Allele Specific PCR; NB-LRR: Nucleotidebinding, leucine-rich repeat; Nupagri: Núcleo de Pesquisa Aplicada à Agricultura; PCR: Polymerase chain reaction; PI-PLC: Phosphoinositide-specific phospholipase-C; PTK: Protein tyrosine kinase; RB: Resistant bulk; SB: Susceptible bulk; SNP: Single nucleotide polymorphism; STK: Serine threonine protein kinase; TNL: N-terminal Toll-interleukin-1 receptor (TIR)-like domain; UEM: Universidade Estadual de Maringá; USDA: United States Department of Agriculture

\section{Acknowledgements}

We would like to thank to Capes and CNPq for scholarship to Sandra Aparecida L. Castro, Thiago Alexandre Santana Gilio, Giselly Figueiredo Lacanallo and Giseli Valentini. We also appreciate the critical reading of the manuscript by Pedrina Gonçalves Vidigal.

\section{Funding}

This research was supported in part by Brazilian Federal Funding Institutions CNPq and Capes. M.C. Gonçalves-Vidigal is grateful for grant from CNPq. This research was also supported, in part, by funding from the Norman Borlaug Commemorative Research Initiative of the US Agency for International Development, project number 0210-22310-004-96R and by the US Department of Agriculture, Agricultural Research Services Project Number 8042-22000286-00D (Pastor-Corrales). The contents of this publication do not necessarily reflect the views or policies of the US Department of Agriculture, nor does mention of trade names, commercial products, or organizations imply endorsement by the US Government.

\section{Availability of data and materials}

The datasets used during the current study are available from the corresponding author on reasonable request.

\section{Authors' contributions}

SALC performed the genetic characterization, contributed to data analysis and drafted the manuscript. MCGV designed the study, analyzed the data and revised the manuscript. TASG conducted the molecular experiment and analyzed the data. GFL and VSRM helped to perform the experiment and data analysis. GV contributed to data analysis and helped to revise the manuscript. QS and MAPC contributed to design and performed the SNP genotyping, data analysis and to revise the manuscript. MZG provided the genetic material. OPHG designed the KASP markers and helped to revise the manuscript. All authors read and approved the final manuscript.

\section{Competing interests}

The authors declare that they have no competing interests.

\section{Consent for publication \\ Not applicable.}

\section{Ethics approval and consent to participate}

The seeds of the common bean cultivars used in this study are from the Laboratório de Melhoramento de Feijão Comum e de Biologia Molecular of the Núcleo de Pesquisa Aplicada à Agricultura (Nupagri), Universidade Estadual de Maringá, Paraná State, Brazil. As well as, the isolates of the races were obtained from the mycology collection of the Laboratório de Melhoramento de Feijão Comum e de Biologia Molecular of the Núcleo de Pesquisa Aplicada à Agricultura (Nupagri), Universidade Estadual de Maringá, Paraná State, Brazil.

\section{Publisher's Note}

Springer Nature remains neutral with regard to jurisdictional claims in published maps and institutional affiliations.

\section{Author details}

'Departamento de Agronomia, Universidade Estadual de Maringá, Maringá, Paraná, Brazil. ${ }^{2}$ Soybean Genomics and Improvement Laboratory, United States Department of Agriculture, Agricultural Research Service, Beltsville, MD, USA. ${ }^{3}$ CONICET, Laboratorio de Biotecnología, Estación Experimental Agropecuaria Salta, Instituto Nacional de Tecnología Agropecuaria, Cerrillos, Salta, Argentina.

Received: 4 November 2016 Accepted: 6 April 2017

Published online: 18 April 2017

\section{References}

1. Broughton WJ, Hernández G, Blair M, Beebe S, Gepts P, Vanderleyden J. Beans (Phaseolus spp.)-model food legumes. Plant Soil. 2003;252:55-128. doi:10.1023/A:1024146710611.

2. Blair MW, González LF, Kimani PM, Butare L. Genetic diversity, inter-gene pool introgression and nutritional quality of common beans (Phaseolus 
vulgaris L.) from Central Africa. Theor Appl Genet. 2010. doi:10.1007/s00122010-1305-X.

3. Gepts P. Phaseolin as an evolutionary marker. In: Gepts P, editor. Genetic resources of Phaseolus beans. Dordrecht: Kluwer Academic Publishers; 1988. p. 215-41.

4. Gepts P, Debouck DG. Origin, domestications, and evolution of the common bean (Phaseolus vulgaris L.). In: van Schoonhoven A, Voysest O, editors. Common beans: research for crop improvement. Cali: CIAT; 1991. p. 7-53.

5. Schmutz J, McClean PE, Mamidi S, Wu GA, Cannon SB, Grimwood J, et al. A reference genome for common bean and genome-wide analysis of dual domestications. Nat Genet. 2014. doi:10.1038/ng.3008.

6. Cichy KA, Porch T, Beaver JS, Cregan PB, Fourie D, Glahn R, et al. A Phaseolus vulgaris diversity panel for Andean bean improvement. Crop Sci. 2015. doi:10.2135/cropsci2014.09.0653.

7. Pastor-Corrales MA, Tu JC. Anthracnose. In: Schwartz HF, Pastor-Corrales MA editors. Bean production problems in the tropics. Cali: CIAT; 1989. p. 77-104.

8. Kelly JD, Vallejo VA. A comprehensive review of the major genes conditioning resistance to anthracnose in common bean. Hort Science. 2004:39:1196-207.

9. Nunes MP, Gonçalves-Vidigal MC, Lacanallo GF, Coimbra GK. Comprehension of Genetic Variability and Virulence of Colletotrichum lindemuthianum in Common Bean. $51^{\text {th }} \mathrm{BIC}$ Meeting, Program and Abstract, p. 13, 2013.

10. Pastor-Corrales MA. Traditional and molecular confirmation of the coevolution of beans and pathogens in Latin America. Ann Rep Bean Improv Coop. 1996;39:46-7.

11. Balardin RS, Jarosz AM, Kelly JD. Virulence and molecular diversity in Colletotrichum lindemuthianum from South, Central, and North America. Phytopathology. 1997. doi:10.1094/PHYTO.1997.87.12.1184.

12. Balardin RS, Kelly JD. Interaction between Colletotrichum lindemuthianum races and gene pool diversity in Phaseolus vulgaris. J Am Soc Hortic Sci. 1998:123:1038-47.

13. Beebe S, Rengifo J, Gaitan E, Duque MC, Tohme J. Diversity and origin of Andean landraces of Common Bean. Crop Sci. 2001. doi:10.2135/ cropsci2001.413854x

14. Méndez-Vigo B, Rodríguez-Suárez C, Pañeda A, Ferreira JJ, Giraldez R. Molecular markers and allelic relationships of anthracnose resistance gene cluster B4 in common bean. Euphytica. 2005:141:237-45.

15. Alzate-Marin AL, Souza KA, Silva MGM, Oliveira EJ, Moreira MA, Barros EG. Genetic characterization of anthracnose resistance genes $\mathrm{CO}^{-} 4^{3}$ and $\mathrm{Co}-9$ in common bean cultivar Tlalnepantla 64 (PI207262). Euphytica. 2007;154:1-8.

16. Gonçalves-Vidigal MC, Silva CR, Vidigal Filho PS, Gonela A, Kvitschal V. Allelic relationships of anthracnose (Colletotrichum lindemuthianum) resistance in the common bean (Phaseolus vulgaris L.) cultivar Michelite and the proposal of a new anthracnose resistance gene, Co-11. Genet Mol Biol. 2007;30:589-93.

17. Rodríguez-Suárez C, Ferreira JJ, Campa A, Pañeda A, Giraldez R. Molecular mapping and intra-cluster recombination between anthracnose racespecific resistance genes in the common bean differential cultivars Mexico 222 and Widusa. Theor Appl Genet. 2008:116:807-14.

18. Geffroy V, Macadre C, David P, Pedrosa-Harand A, Sévignac M, Dauga C, et al. Molecular analysis of a large subtelomeric nucleotide-binding-siteleucine-rich-repeat family in two representative genotypes of the major gene pools of Phaseolus vulgaris. Genetics. 2009;181:405-19. doi:10.1534/ genetics.108.093583.

19. Vallejo V, Kelly JD. New insights into the anthracnose resistance of common bean landrace G 2333. Open Hortic J. 2009. doi:10.2174/ 1874840600902010029

20. Campa A, Giraldez R, Ferreira JJ. Genetic analysis of the resistance to eight anthracnose races in the common bean differential cultivar Kaboon. Phytopathology. 2011;101:757-64.

21. Gonçalves-Vidigal MC, Cruz AS, Garcia A, Kami J, Vidigal Filho PS, Sousa LL, et al. Linkage mapping of the Phg-1 and $\mathrm{Co}^{-1} \mathrm{I}^{4}$ genes for resistance to angular leaf spot and anthracnose in the common bean cultivar AND 277. Theor Appl Genet. 2011. doi:10.1007/s00122-010-1496-1.

22. Gonçalves-Vidigal MC, Cruz AS, Lacanallo GF, Vidigal Filho PS, Sousa LL, Pacheco CMNA, et al. Co-segregation analysis and mapping of the anthracnose $\mathrm{Co}-10$ and angular leaf spot Phg-ON disease-resistance genes in the common bean cultivar Ouro Negro. Theor Appl Genet. 2013. doi:10.1007/s00122-013-2131-8.

23. Richard MS, Pflieger S, Sévignac M, Thareau V, Blanchet $S$, Li Y, et al. Fine mapping of $\mathrm{Co}-\mathrm{X}$, an anthracnose resistance gene to a highly virulent strain of Colletotrichum lindemuthianum in common bean. Theor Appl Genet. 2014. doi:10.1007/s00122-014-2328-5.

24. Sousa LL, Cruz AS, Vidigal Filho PS, Vallejo VA, Kelly JD, Gonçalves-Vidigal MC. Genetic mapping of the resistance allele Co- $5^{2}$ to Colletotrichum lindemuthianum in the common bean MSU 7-1 line. Aust J Crop Sci. 2014;8:317-23.

25. Trabanco N, Campa A, Ferreira JJ. Identification of a new chromosomal region involved in the genetic control of resistance to anthracnose in common bean. The Plant Genome. 2015;8:1-11. doi:10.3835/ plantgenome2014.10.0079.

26. Coimbra-Gonçalves GK, Gonçalves-Vidigal MC, Coelho RT, Valentini G, Vidigal Filho PS, Lacanallo GF, et al. Characterization and mapping of anthracnose resistance genes in Mesoamerican common bean cultivar Crioulo 159. Crop Sci. 2016. doi:10.2135/cropsci2015.10.0651.

27. Gonçalves-Vidigal MC, Kelly JD. Inheritance of anthracnose resistance in the common bean cultivar Widusa. Euphytica. 2006. doi:10.1007/s10681-006-9164-x.

28. Gonçalves-Vidigal MC, Lacanallo GF, Vidigal PS. A new Andean gene conferring resistance to anthracnose in common bean (Phaseolus vulgaris L.) cultivar Jalo Vermelho. Plant Breed. 2008;127:592-6.

29. Gonçalves-Vidigal MC, Vidigal Filho PS, Medeiros AF, Pastor-Corrales MA. Common bean landrace Jalo Listras Pretas is the source of a new Andean anthracnose resistance gene. Crop Sci. 2009:49:133-8.

30. Gonçalves-Vidigal MC, Meirelles AC, Poletine JP, Sousa LL, Cruz AS, Nunes MP, et al. Genetic analysis of anthracnose resistance in 'Pitanga' dry bean cultivar. Plant Breed. 2012;131:423-9.

31. Lacanallo GF, Gonçalves-Vidigal MC. Mapping of an Andean gene for anthracnose resistance (Co-13) in common bean (Phaseolus vulgaris L.) Jalo Listras Pretas landrace. Aust J Crop Sci. 2015;9:394-400.

32. Sousa LL, Gonçalves AO, Gonçalves-Vidigal MC, Lacanallo GF, Fernandez AC, Awale $\mathrm{H}$, et al. Genetic characterization and mapping of anthracnose resistance of common bean landrace cultivar Corinthiano. Crop Sci. 2015;55:1-11.

33. Gonçalves-Vidigal MC, Pacheco CMNA, Vidigal Filho PS, Lacanallo GF, Sousa LL, Martins VSR. Genetic mapping of the anthracnose resistance gene Co-14 in the common bean cultivar Pitanga. Ann Rep Bean Improv Coop. 2016;59:55-6.

34. Geffroy V, Sicard D, Oliveira JCF, Sévignac M, Cohen S, Gepts P, et al. Identification of an ancestral resistance gene cluster involved in the coevolution process between Phaseolus vulgaris and its fungal pathogen Colletotrichum lindemuthianum. Mol Plant Microbe Interact. 1999. doi:10.1094/MPMI.1999.12.9.774

35. Galván MZ, Aulicino MB, Medina SG, Balatti PA. Genetic diversity among Northwestern Argentinian cultivars of common bean (Phaseolus vulgaris L.) as revealed by RAPD markers. Genet Resour Crop Ev. 2001;48:251-60.

36. Cárdenas F, Adams MW, Andersen A. The genetic system for reaction of field beans (Phaseolus vulgaris L.) to infection by three physiologic races of Colletotrichum lindemuthianum. Euphytica. 1964;13:178-86.

37. Pastor-Corrales MA, Otoya MM, Molina A, Singh SP. Resistance to Colletotrichum lindemuthianum isolates from Middle America and Andean South America in different common bean races. Plant Dis. 1995;79:63-7.

38. Pastor-Corrales MA. Recomendaciones y acuerdos del primer taller de antracnosis en América Latina. In: Pastor-Corrales MA, editor. La antracnosis del frijol común, Phaseolus vulgaris, en América Latina. Cali: CIAT; 1992. p. 240-50.

39. Zuiderveen GH, Padder BA, Kamfwa K, Song Q, Kelly JD. Genome-wide association study of anthracnose resistance in andean beans (Phaseolus vulgaris). Plos One. 2016. doi:10.1371/journal.pone.0156391.

40. Michelmore RW, Paran I, Kesseli RV. Identification of markers linked to disease resistance genes by bulked segregant analysis: a rapid method to detect markers in specific genomic regions using segregating populations. Proc Natl Acad Sci U S A. 1991;88:9828-32.

41. Song Q, Jia G, Hyten DL, Jenkins J, Hwang E-Y, Schroeder S, et al. SNP assay development for linkage map construction, anchoring whole genome sequence and other genetic and genomic applications in common bean. G3. 2015. doi:10.1534/g3.115.020594.

42. Song Q, Hyten DL, Jia G, Quigley CV, Fickus EW, Nelson RL, et al. Development and evaluation of SoySNP50K, a high-density genotyping array for soybean. Plos One. 2013. doi:10.1371/journal.pone.0054985.

43. Cruz CD. GENES - a software package for analysis in experimental statistics and quantitative genetics. Acta Sci Agron. 2013. doi:10.4025/actasciagron. v35i3.21251.

44. Van Ooijen JW. Multipoint maximum likelihood mapping in a full-sib family of an outbreeding species. Genet Res. 2011;93:343-9. 
45. Voorrips RE. Mapchart: software for the graphical presentation of linkage maps and QTLs. J Hered. 2002. doi:10.1093/jhered/93.1.77.

46. Pastor-Corrales MA, Aime MC. Differential cultivars and molecular markers segregate isolates of Uromyces appendiculatus into two distinct groups that correspond to the gene pools of their common bean hosts. Phytopathology. 2004;94:82.

47. Balardin RS. Identificação de raças fisiológicas de Colletotrichum lindemutianum no Rio Grande do Sul, Brazil. Fitopatol Bras. 1997;22:50-3.

48. Kelly JD, Gepts P, Miklas PN, Coyne DP. Tagging and mapping of genes and QTL and molecular marker-assisted selection for traits of economic importance in bean and cowpea. Field Crop Res. 2003;82:135-54.

49. Miklas PN, Kelly JD, Beebe SE, Blair MW. Common bean breeding for resistance against biotic and abiotic stresses: From classical to MAS breeding. Euphytica. 2006;147:105-13.

50. Geffroy $V$, Sévignac M, Billant $P$, Dron M, Langin T. Resistance to Colletotrichum lindemuthianum in Phaseolus vulgaris: a case study for mapping two independent genes. Theor Appl Genet. 2008. doi:10.1007/ s00122-007-0678-y.

51. Meyers BC, Kaushik S, Nandety RS. Evolving disease resistance genes. Curr Opin Plant Biol. 2005;8:129-34.

Submit your next manuscript to BioMed Central and we will help you at every step:

- We accept pre-submission inquiries

- Our selector tool helps you to find the most relevant journal

- We provide round the clock customer support

- Convenient online submission

- Thorough peer review

- Inclusion in PubMed and all major indexing services

- Maximum visibility for your research

Submit your manuscript at www.biomedcentral.com/submit
Biomed Central 